\title{
MUSEO DE LA PLATA RADIOCARBON MEASUREMENTS II
}

\author{
ANIBAL J FIGINI, JORGE E CARBONARI and ROBERTO A HUARTE \\ Laboratorio de Tritio y Radiocarbono (LATYR), Facultad de Ciencias \\ Naturales y Museo, Paseo del Bosque, 1900 La Plata, Argentina
}

\section{INTRODUCTION}

The ${ }^{14} \mathrm{C}$ measurements reported here were made between 1983 and 1987. Sample pretreatment and date calculations were previously reported (Figini et al 1984). The method employed, liquid scintillation counting, was previously described (Huarte \& Figini 1988). No ${ }^{13} \mathrm{C} /{ }^{12} \mathrm{C}$ ratios were measured and results were not corrected for ${ }^{13} \mathrm{C}$ fractionation and/or reservoir effect. Descriptions, comments and references to publications are based on information supplied by submitters.

\section{ACKNOWLEDGMENTS}

The authors wish to express their thanks to the Consejo Nacional de Investigaciones Científicas y Técnicas (CONICET), Argentina, for their financial support and to the Facultad de Ciencias Naturales y Museo (FCNyM), Universidad Nacional de La Plata. Our special gratitude goes to the Centro de Estudios Parasitológicos y de Vectores (CEPAVE), for the use of their liquid scintillation spectrometer and to Myriam Tarragó for critically evaluating the archaeological section of this date list.

\section{GEOLOGIC SAMPLES}

Argentina

\section{LP-82. Glaciar del Río Manso}

$180 \pm 60$

Wood (Nothofagus sp) identified by A Brandani, CONICET and J Bruno, Parques Nacionales, from outcrop of glacio-lacustrine deposit in contact with ice in lateral moraine, at $12 \mathrm{~m}$ depth below top of moraine ( $41^{\circ} 10^{\prime} \mathrm{S}, 71^{\circ} 50^{\prime} \mathrm{W}$ ) Cerro Tronador, Río Negro Prov. Coll and subm Feb 1983 by J Rabassa, Comm Inv Cient Prov Buenos Aires.

Comment (JR): sample directly assoc with neoglacial fluctuations of Río Manso glacier probably related to "Little Ice Age."

\section{LP-100. Estancia Manuil Malal}

$>36,000$

Wood (Nothofagus sp) identified by J Boninsegna and R Villalba, Inst Argentino Nivología Glaciología (IANIGLA), Mendoza Prov, from outcrop below El Condor till and glacio-lacustrine deposit corresponding to ice margin lake $\left(39^{\circ} 30^{\prime} \mathrm{S}, 71^{\circ} 15^{\prime} \mathrm{W}\right)$, Junín de los Andes, Neuquén Prov. Coll and subm Dec 1983 by J Rabassa.

Comment (JR): correlation with beginning of El Condor glaciation. Estimated age: 40,000 yr. Another portion of same sample was dated at 27,740 \pm 555 (SI-6384; Stuckenrath, pers commun).

\section{Punta Hermengo series}

Estuarine sediments containing mollusk shells from valley-fill deposit of Late Pleistocene and 
Holocene ages, Punta Hermengo ( $\left.38^{\circ} 18^{\prime} \mathrm{S}, 57^{\circ} 52^{\prime} \mathrm{W}\right)$, Miramar, Buenos Aires Prov. Samples coll and subm 1981 by F Fidalgo and J Figini, FCNyM.

\section{LP-86. Sample I}

$3400 \pm 110$

Carbonate powder dispersed into sandy-silt sediment from exposed profile below Puesto Berrondo buried soil.

Comment: no pretreatment.

LP-87. Sample II

$6680 \pm 140$

Shells (Litoridina parchappei) from exposed profile underlying Puesto Berrondo buried soil and Puesto Callejon Viejo paleosol.

Comment: no acid pretreatment.

General Comment: ages agree with proposed paleontologic-geologic sequence by Fidalgo and Tonni (1983) for upper continental sediments.

\section{Arroyo Seco series}

Pedogenic carbonate from stratigraphic sequence at archaeol Site $2\left(38^{\circ} 21^{\prime} 38^{\prime \prime} \mathrm{S}, 60^{\circ} 14^{\prime} 39^{\prime \prime} \mathrm{W}\right)$, Arroyo Seco, Tres Arroyos, Buenos Aires Prov. Coll April 1981 by F Fidalgo and LATYR personnel.

LP-92. Sample I

$1890 \pm 80$

Pedogenic carbonate from silty-sand sediment, $6 \% \mathrm{CaCO}_{3}$ conc, $0.7 \mathrm{~m}$ depth.

Comment: no pretreatment. Age is younger than expected probably due to contamination by young carbon dissolved in meteoric waters that penetrated profile.

LP-93. Sample II

$5740 \pm 120$

Pedogenic carbonate from silt with sand and clay sediment, $16 \% \mathrm{CaCO}_{3}$ conc, $0.75 \mathrm{~m}$ depth.

Comment: no pretreatment.

LP-94. Sample III

$5700 \pm 120$

Pedogenic carbonate from silt with clay and sand sediment, $14 \% \mathrm{CaCO}_{3}$ conc, $0.85 \mathrm{~m}$ depth. Comment: no pretreatment.

General Comment: concordance between LP-93 and -94 ages shows that this horizon corresponds to same weathering process. Chronologic sequence agrees with stratigraphic position of samples and other dates from same site (LP-53, $8390 \pm 240$ (Figini et al 1984: 132)).

\section{Teatro Argentino series}

Continental sediments named "Sedimentos Pampeanos" from ca $30 \mathrm{~m}$ profile of Teatro Argentino building, La Plata city ( $34^{\circ} 54^{\prime} 36^{\prime \prime}$ S, 57 $56^{\prime} 03^{\prime \prime}$ W), Buenos Aires Prov. Coll May 1981 by F Fidalgo and LATYR personnel. 
LP-95. Sample I

$13,160 \pm 230$

Pedogenic carbonate from $2.5 \mathrm{~m}$ depth in sandy-clay silt sediment, $28 \% \mathrm{CaCO}_{3}$ by weight.

LP-96a. Sample II

$15,300 \pm 260$

Pedogenic carbonate from $5 \mathrm{~m}$ depth in the same sediment as $\mathrm{LP}-95,56 \% \mathrm{CaCO}_{3}$ by weight.

LP-96b.

$14,570 \pm 280$

Duplicate of LP-96a.

LP-98. Sample III

$>\mathbf{3 7 , 0 0 0}$

Pedogenic carbonate from $8.5 \mathrm{~m}$ below discontinuous contact corresponding to one incipient $\mathrm{K}$ horizon. $\mathrm{CaCO}_{3}$ from sandy-silt clay sediment, $10 \%$ by weight.

LP-99. Sample IV

$32,700 \pm 1400$

Pedogenic carbonate from $9.5 \mathrm{~m}$ depth below LP-98 in same sediment, $18 \% \mathrm{CaCO}_{3}$ by weight. Comment: age is pooled mean of two determinations: LP-99a: 32,900 \pm 1900 and LP-99b: 32,600 \pm 2200 .

General Comment: ${ }^{14} \mathrm{C}$ ages agree with relative age of lithostratigraphic units; also they show more than one pedogenic cycle. LP-99 is probably contaminated by modern carbon; thus, age would be $>32,700 \mathrm{yr}$. Age sediments cannot be established through palaeontologic or geologic evidence; Late Pleistocene age is suggested.

\section{Las Escobas III series}

Mollusk shells from Holocene marine coastal deposit belonging to Cerro de la Gloria member of Las Escobas Fm (Fidalgo, De Francesco \& Colado 1973) at exposed profile in Rincon de Lopez $\left(35^{\circ} 46^{\prime} 07^{\prime \prime} \mathrm{S}, 57^{\circ} 24^{\prime} 30^{\prime \prime} \mathrm{W}\right)$, Castelli, Buenos Aires Prov. Coll 1980-1982 by F Fidalgo and LATYR personnel. Shells identified by D Fernandez, FCNyM; calcite/aragonite x-ray diffraction analyses by M Iñiguez Rodriguez, FCNyM.

\section{LP-111. Sample I, Site 1}

$3150 \pm 70$

Shells (Mactra isabelleana) ca $1.9 \mathrm{~m}$ depth below surface.

Comment: outer $20 \%$ of shells removed by acid pretreatment; remaining portion consisting of $4.9 \%$ calcite, $95.1 \%$ aragonite, was dated.

LP-112A. Sample II, Site 1

$3150 \pm 90$

LP-112B. Sample II, Site 1

$3050 \pm 90$

Shell (Adelomedon brasiliana) ca $1.9 \mathrm{~m}$ depth below surface, assoc with LP-111.

Comment: LP-112A was outer $20 \%$ of shell removed by acid pretreatment and dated; remaining portion, $-112 \mathrm{~B}$, consisting of $0.7 \%$ calcite and $98.3 \%$ aragonite, was dated. 
LP-114A. Sample III, Site 1

$6460 \pm 110$

LP-114B. Sample III, Site 1

$7220 \pm 100$

Shell (Adelomedon brasiliana) ca 1.9m depth below surface, assoc with LP-111 and -112.

Comment: LP-114A was outer $20 \%$ of shell removed by acid pretreatment and dated; remaining portion, $-114 \mathrm{~B}$, consisting of $100 \%$ aragonite, was dated.

LP-116. Sample IV, Site 2

$3490 \pm 80$

Shells (Mactra isabelleana) ca $2 \mathrm{~m}$ below surface, $3.25 \mathrm{~m}$ from Site 1 .

Comment: outer $20 \%$ of shells removed by acid pretreatment and discarded; inner fraction, consisting of $2.9 \%$ calcite and $97.1 \%$ aragonite, was dated.

LP-117A. Sample V, Site 2

$4320 \pm 80$

LP-117B. Sample V, Site 2

$3760 \pm 60$

Shell (Adelomedon brasiliana) ca $2 \mathrm{~m}$ below surface, assoc with LP-116.

Comment: LP-117A was outer $20 \%$ of shell removed by acid pretreatment and dated; remaining portion, $-117 \mathrm{~B}$, consisting of $1 \%$ calcite and $99 \%$ aragonite, was dated.

LP-119A. Sample VI, Site 2

$4760 \pm 110$

LP-119B. Sample VI, Site 2

$4910 \pm 110$

Shell (Adelomedon brasiliana) ca $2 \mathrm{~m}$ below surface, assoc with LP-116 and -117 .

Comment: LP-119A was outer $20 \%$ of shell removed by acid pretreatment and dated; remaining portion, $-119 \mathrm{~B}$, consisting of 8.6 calcite and $91.4 \%$ aragonite, was dated.

LP-121A. Sample VII, Site 2

$3460 \pm 70$

LP-121B. Sample VII, Site 2

$\mathbf{3 3 3 0} \pm \mathbf{5 0}$

Shell (Adelomedon brasiliana) ca $2 \mathrm{~m}$ below surface, assoc with LP-116, -117 and -119 .

Comment: LP-121A was outer $20 \%$ of shell removed by acid pretreatment and dated; remaining portion, $-121 \mathrm{~B}$, consisting of $8 \%$ calcite and $92 \%$ aragonite, was dated.

LP-124A. Sample VIII, Site 2

LP-124B. Sample VIII, Site 2

$6850 \pm 90$

$6340 \pm 90$

Shell (Adelomedon brasiliana) ca $2 \mathrm{~m}$ below surface, assoc with LP-116, -117, -119 and -121 .

Comment: LP-124A was outer $20 \%$ of shell removed by acid pretreatment and dated; remaining portion, $-124 \mathrm{~B}$, consisting of $7.7 \%$ calcite and $92.3 \%$ aragonite, was dated.

General Comment: shells died at different ages and were redeposited, which is consistent with nature of deposit.

\section{Las Escobas IV series}

Mollusk shells belonging to Cerro de La Gloria member of Las Escobas Fm, from exposed profile of Canal $15\left(35^{\circ} 58^{\prime} 21^{\prime \prime} \mathrm{S}, 57^{\circ} 29^{\prime} 16^{\prime \prime} \mathrm{W}\right)$. Samples were extracted in vertical sequence; identified by $\mathrm{D}$ Fernandez; calcite/aragonite $\mathrm{x}$-ray diffraction analyses by $\mathrm{M}$ Iñiguez Rodriguez. 
LP-110. Sample 14

$4510 \pm 110$

Shells (Mactra isabelleana) from ca $0.60 \mathrm{~m}$ depth; outer $20 \%$ of shell removed by acid; remaining portion consisting of $25 \%$ calcite and $75 \%$ aragonite, was dated.

\section{LP-147. Sample 14}

$4220 \pm 110$

Shells (Mactra isabelleana) from ca $0.60 \mathrm{~m}$ depth; outer $35 \%$ of shell removed by acid pretreatment and dated, remaining portion was discarded; calcite was not determined.

\section{LP-109. Sample 13}

$4550 \pm 100$

Shells (Mactra isabelleana) from ca $1 \mathrm{~m}$ depth; outer $20 \%$ of shell removed by acid; remaining portion consisting of $30 \%$ calcite and $70 \%$ aragonite, was dated.

LP-154. Sample 13

$4610 \pm 90$

Shells (Mactra isabelleana) from ca $1 \mathrm{~m}$ depth; outer $35 \%$ of shell removed by acid pretreatment and dated, inner portion was discarded; calcite was not determined.

\section{LP-108. Sample 12}

$4800 \pm 90$

Shells (Mactra isabelleana) from ca $1.60 \mathrm{~m}$ depth; outer $20 \%$ of shell removed by acid; remaining portion consisting of $5 \%$ calcite and $95 \%$ aragonite, was dated.

\section{LP-158. Sample 12}

$4680 \pm 70$

Shells (Mactra isabelleana) from ca $1.60 \mathrm{~m}$ depth; outer $35 \%$ of shell removed by acid pretreatment and dated, remaining portion was discarded; calcite was not determined.

\section{LP-107. Sample 11}

$4440 \pm 110$

Shells (Mactra isabelleana) from ca $2.40 \mathrm{~m}$ depth; outer $20 \%$ of shell removed by acid; remaining portion consisting of $100 \%$ aragonite, was dated.

General Comment: Samples 12, 13 and 14 were divided into two portions for dating inner and outer fractions.

\section{LP-113. Río Sauce Grande-La Toma}

$1150 \pm 70$

Wood (Salix humboldtiana) identified by $\mathrm{J}$ Bonisegna and $\mathrm{R}$ Villalba, IANIGLIA, from outcrop, $6 \mathrm{~m}$ deep from top of ravine, Río Sauce Grande-La Toma $\left(38^{\circ} 15^{\prime} \mathrm{S}, 61^{\circ} 45^{\prime} \mathrm{W}\right)$, Buenos Aires Prov. Coll and subm Feb 1984 by J Rabassa.

Comment (JR): Lujanese mammalian age estimated by correlation with strata containing extinct fauna. Other portion of same sample was dated at $1570 \pm 45$ (SI-6848; Stuckenrath, pers commun).

\section{Cueva Tixi series}

Carbonate layers in stratigraphic sequence of Tixi cave $\left(37^{\circ} 58^{\prime} 30^{\prime \prime} \mathrm{S}, 58^{\circ} 04^{\prime} 04^{\prime \prime} \mathrm{W}\right)$, containing palaeontologic and archaeologic debris, in slope of La Vigilancia range, General Alvarado, Buenos Aires Prov. Coll Dec 1983 by F Fidalgo and LATYR personnel. 
LP-140. Sample I

$1220 \pm 70$

Carbonate from layer, $0.23 \mathrm{~m}$ thick, at top of stratigraphic sequence.

Comment: no pretreatment was made.

\section{LP-139. Sample II}

$1730 \pm 80$

Carbonate from layer, $0.05 \mathrm{~m}$ thick, $0.38 \mathrm{~m}$ depth below LP-140.

Comment: no pretreatment was made.

General Comment: these ages agree with stratigraphic sequence and relative chronology based on faunal remains.

\section{Valle del Rio Sauce Grande series}

Snail shells from Upper Pleistocene and Holocene continental deposits corresponding to Agua Blanca Fm and Saavedra Fm. Coll and subm Feb 1985 by J Rabassa. Mollusk shells identified by $\mathrm{D}$ Fernandez; $\mathrm{x}$-ray diffraction analyses by $\mathrm{M}$ Iñiguez Rodriguez.

\section{LP-115. Balneario Saldungaray SG 96}

$32,300 \pm 1800$

Snail shells (Plagiodontes patagonicus) dispersed through middle sandy member of Agua Blanca Fm at $210 \mathrm{~m}$ above msl ( $\left.38^{\circ} 12^{\prime} \mathrm{S}, 61^{\circ} 46^{\prime} \mathrm{W}\right)$, Saldungaray, Buenos Aires Prov.

Comment: inner fraction (70\%) was used with $2 \%$ calcite and $98 \%$ aragonite.

LP-118. Camino Saldungaray RP 51

$9780 \pm 140$

Snail shells (Plagiodontes patagonicus) dispersed through piedmont deposit of superior member of $\mathrm{La}$ Toma $\mathrm{Fm}$ at $180 \mathrm{~m}$ above msl (38 $\left.14^{\prime} \mathrm{S}, 61^{\circ} 43^{\prime} \mathrm{W}\right)$, Ruta Provincial 51, Saldungaray.

Comment: inner fraction was used with $10 \%$ calcite and $90 \%$ aragonite.

\section{LP-120. Lartigau}

$113.9 \pm 0.7 \mathrm{pMC}$

Snail shells (Plagiodontes patagonicus) coll alive on shrubs growing on outcrop of La Toma $\mathrm{Fm}$ at $180 \mathrm{~m}$ above msl $\left(38^{\circ} 23^{\prime} \mathrm{S}, 61^{\circ} 38^{\prime} \mathrm{W}\right)$ Lartigau, Buenos Aires Prov.

Comment: flesh was separated from shell in boiling water; inner shell fraction (90\%) was used.

General Comment: snail shells (Plagiodontes patagonicus and Austroborus lutescens) from upper member of Saavedra Fm were dated at $5500 \pm 200$ and $3890 \pm 110$ (SI-6450A and SI-6450B; Stuckenrath, pers commun). LP-118 and both SI ages agree with Holocene age of these stratigraphic units. LP-115 confirms Upper Pleistocene age of unit, which had been attributed to Lujanese mammalian age. LP-120 shows current depletion of ${ }^{14} \mathrm{C}$ atmospheric level marked by snails.

\section{La Plata Eubalena series}

Mandibular branch (Eubalena australis) from Holocene marine sediments corresponding to Las

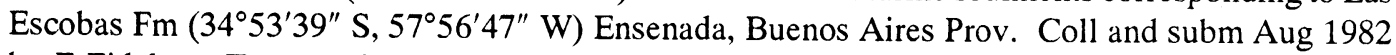
by F Fidalgo. Taxonomic determination was made by E Tonni, FCNyM. 


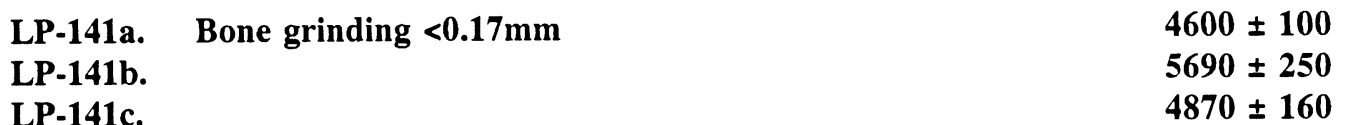

Comment: each sample was pretreated according to Longin (1971) in 1M HCL for $15 \mathrm{~min}$.

\begin{tabular}{|c|c|}
\hline $\begin{array}{l}\text { LP-141d. } \\
\text { LP-141e. } \\
\text { LP-141f. } \\
\text { LP-141g. } \\
\text { LP-141h. } \\
\text { LP-141i. }\end{array}$ & Bone grinding $<2.0 \mathrm{~mm}$ \\
\hline
\end{tabular}

Comment: each sample was pretreated in $1 \mathrm{M} \mathrm{HCL}$ for $24 \mathrm{hr}$ in vacuum.

General Comment: in this study, we have introduced variations in pretreatment (time and particlesize) in order to recover the maximum protein content and assure the total dissolution of inorganic matrix. We did not obtain a complete acid dissolution of inorganic matrix in LP-141a, -141b and -141c. We obtained a complete acid dissolution of bone and an increase of protein flocculate in LP-141d, $-141 \mathrm{e},-141 \mathrm{f},-141 \mathrm{~g},-141 \mathrm{~h}$ and $-141 \mathrm{i}$. In all cases, collagen was extracted according to Longin (1971) in $\mathrm{HCL}$ solution $\mathrm{pH} 2-3$ at $80^{\circ} \mathrm{C}$ for $24 \mathrm{hr}$ and used for dating. Several determinations were made to evaluate variability of dates.

\section{LP-141j Total bone acidification}

$1060 \pm 90$

Comment: $\mathrm{CO}_{2}$ from acid evolution of bone sample. This result shows trend of inorganic contamination.

\section{Baradero series}

Bone (Balaenoptera cf physalus) from estuarine sediments corresponding to Las Escobas Fm near Baradero city ( $33^{\circ} 50^{\prime} \mathrm{S}, 59^{\circ} 30^{\prime} \mathrm{W}$ ) Buenos Aires Prov, from $0.30-0.50 \mathrm{~m}$ depth. Coll July 1986 by A Figini and F Fidalgo, identified by E Tonni.

LP-153a.

$5630 \pm 100$

Collagen.

LP-153b.

$5420 \pm 110$

Duplicate.

Comment: both samples were pretreated in $1 \mathrm{M} \mathrm{HCL}$ for $24 \mathrm{hr}$ in vacuum; collagen was extracted according to Longin (1971). Pooled mean was reported as LP-153: $5540 \pm 80$.

LP-153c.

$2710 \pm 110$

$\mathrm{CO}_{2}$ from bone acidification.

Comment: this age shows trend of inorganic contamination.

\section{Lobería series}

Bone sample from continental deposit of Late Pleistocene and Holocene ages, corresponding 
to La Postrera Fm, Lobería ( $\left.38^{\circ} 09^{\prime} \mathrm{S}, 58^{\circ} 48^{\prime} \mathrm{W}\right)$, Buenos Aires Prov. Coll, identified and subm Aug 1986 by E Tonni.

LP-152a.

$10,590 \pm 120$

Collagen from dermal ossicles of Glossotherium (Pseudolestodon) myloides.

LP-152b.

$10,860 \pm 130$

Duplicate.

Comment: pretreatment and collagen extraction of both samples equal to LP-153a and $-153 \mathrm{~b}$. Pooled mean reported was LP-152: $10,710 \pm 90$.

LP-152c.

$4150 \pm 90$

$\mathrm{CO}_{2}$ from bone acidification.

Comment: this age shows trend of inorganic contamination.

ARCHAEOLOGIC SAMPLES

Argentina

\section{LP-85. CPV/96 Pichileufú}

$2530 \pm 90$

Charcoal from occupational floor at 0.68-0.70m depth, level VIII, Río Pichileufú Cave $\left(41^{\circ} 04^{\prime}\right.$ S, $70^{\circ} 52^{\prime}$ W), Pilcaniyeu, Río Negro Prov. Coll and subm March 1981 by R Ceballos, Fac Humanidades, Univ Nac Rosario (UNR).

Comments (RC): corresponds to postglacial guanaco hunters of Northern Patagonia. (Myriam Tarragó (MT)): provides ante quem date for wall engravings which were covered by Levels I-XI. Such engravings are supposedly related to the cave's most ancient inhabitants. See Ceballos and Peronja (1983) for discussion.

\section{LP-88. Fortin Marias II ó Fortin Necochea, Locus 2}

$6010 \pm 400$

Collagen from guanaco bone fragments at 0.9-1.0 below datum, Quad C21, Fortin Necochea $\left(37^{\circ} 23^{\prime} 49^{\prime \prime} \mathrm{S}, 61^{\circ} 08^{\prime} 15^{\prime \prime} \mathrm{W}\right)$, near La Madrid city, Buenos Aires Prov. Coll by M Silveira and E Crivelli and subm Jun 1981 by A Sanguinetti, Inst Antrop, Fac Filosofía y Letras, Univ Nac Buenos Aires, (UBA).

Comments (MS-EC): dates early (but not first) occupation of an open-air stratified site. (MT): consistent with CSIC-593: $3630 \pm 60$. See Crivelli, Eugenio and Silveira (1987-1988) for discussion.

\section{LP-89. Guayra Azul I}

$1100 \pm 60$

Charcoal at $0.26 \mathrm{~m}$ depth, Layer 2, Sec 3, Alero Guayra Azul I (22 $\left.57^{\prime} 56^{\prime \prime} \mathrm{S}, 66^{\circ} 15^{\prime} 16^{\prime \prime} \mathrm{W}\right)$, Cochinoca, Jujuy Prov. Coll by A Fernandez Distel and subm Jun 1981 by M Califano, Centro Argentino Etnol Am, CAEA.

Comments (MC): evaluation of hypothesis about aboriginal relations with San Pedro de Atacama, Chile. (MT): corresponds to Late Formative period of Quebrada de Humahuaca and Puna region's 
chronologic sequence. It would be contemporary to Tiahuanaco Expansive period of both Atacama region and Bolivian Highlands.

LP-91. Abra de la Ventana

$6230 \pm 90$

Charcoal at $0.4-0.7 \mathrm{~m}$ depth, Cueva del Abra $\left(38^{\circ} 05^{\prime} \mathrm{S}, 62^{\circ} \mathrm{W}\right)$ Sierra de la Ventana region, Buenos Aires Prov. Coll and subm June 1979 by A Castro, Fac Ciencias Nat y Museo (FCNyM), Univ Nac La Plata (UNLP).

Comment (AC): this is the first date for lithic material that corresponds to Tandiliense industry in this cave, and represents an early occupation of Pampa Bonaerense.

\section{LP-90. Los Matos II}

$2670 \pm 70$

Charcoal from archaeologic refuse at $0-0.40 \mathrm{~m}$ depth, Test Pit B, Los Matos II, Quebrada de Los Matos $\left(25^{\circ} 07^{\prime} \mathrm{S}, 64^{\circ} 52^{\prime} \mathrm{W}\right)$, Anta Dept, Salta Prov. Coll and subm Oct 1983 by A Fernandez, FCNyM.

Comments (AF): charcoal specks dispersed throughout deposit. Date should determine chronologic span of La Candelaria culture at AD 400-700. (MT): date was rejected because deposits were disturbed by bulldozer's action and date did not correspond to what was expected.

\section{Inca Cueva series}

Samples from Layer 2, Inca Cueva $4\left(\mathrm{IC}_{\mathrm{c}} 4\right)$, Quebrada de Inca Cueva $\left(23^{\circ} \mathrm{S}, 65^{\circ} 27^{\prime} \mathrm{W}\right)$, Humahuaca Dept, Jujuy Prov. Coll and subm Nov 1983 by C Aschero, Inst Nac Antrop, Buenos Aires.

LP-102. M-2

$9650 \pm 110$

Charcoal at $0.50-0.53 \mathrm{~m}$ depth, Quad L3a.

LP-137. M-1

$10,620 \pm 140$

Stem and leaves (Hypsocharis $\mathrm{sp}$ ) at $0.45-0.52 \mathrm{~m}$ depth, Quad M4a.

Comment: sample was boiled in $2 \%$ HCL.

General Comments (CA): date should determine relative synchrony in presumed occupation level. Samples correspond to different quadrants and deposition episodes in refuse area. (MT): LP-102 and -137 respectively, date medium and lower strata. Both samples agree with AC-564: $9900 \pm$ 200 and CSIC-4980: $9230 \pm 70$ from habitation area. The four dates correspond to archaic huntergatherer occupation level in rock-painting shelter. Layer 2 includes several features such as subcircular room floor, postholes and five storage pits dug into sandy substrate. Stemless triangular dart points are similar to those recovered at Huachichocana III-E3 (Tumbaya Dept), La Cueva (Yavi Dept) both in Jujuy Prov and Tuina in northern Chile. See Aschero (1980) for discussion.

\section{LP-104. Cabo San Pablo 1}

$290 \pm 70$

Charcoal from shell midden at $0.25-0.28 \mathrm{~m}$ depth, Cabo San Pablo region, Tierra del Fuego. Coll and subm Nov 1983 by L Borrero, Inst Ciencias Antrop, UBA. 
Comment (LB): dates cultural remains assoc with Selk'nam technology. Should provide chronologic framework for human occupation of Cabo San Pablo area and its inter-site relations.

\section{LP-105. Antumpa R II G-5}

$1360 \pm 70$

Bone fragments (mostly Lama sp) from circular dwelling at Antumpa (22 $59^{\prime} \mathrm{S}, 65^{\circ} 21^{\prime} \mathrm{W}$ ), Quebrada de Humahuaca, Jujuy Prov. Coll and subm Aug 1982 by S Renard de Coquet and M Hernandez Llosas, Inst Antrop Hist Hispanoamericana, Buenos Aires.

Comments (SRC \& MHL): date should provide chronologic framework for occupation of circular dwelling in agricultural village of Quebrada de Humahuaca area. (MT): this is one of first dates for this area which places site towards end of Early Formative period of northwestern Argentina. See Hernandez Llosas, Renard and Podestá (1983-1985).

\section{LP-136. Los Toldos M3 85}

$4850 \pm 90$

Charcoal fragments from $0.35-0.45 \mathrm{~m}$ depth, in topmost Layer 4 and beneath ash layer, Cave 3, Los Toldos ( $47^{\circ} 28^{\prime}$ S, $68^{\circ} 50^{\prime}$ W), Santa Cruz Prov. Coll and subm March 1985 by A Cardich, FCNyM.

Comments (AC): date should provide chronology of Casapedrense occupation in this cave. (MT): confirms relationship between end of Casapedrense lithic industry occupation and cave's volcanic ash layer.

\section{LP-142. Pueblo Viejo de la Cueva}

$1180 \pm 50$

Charcoal from hearth at $0.60-1.0 \mathrm{~m}$ depth, Level III-V, Sec 1, Quad A, Pueblo Viejo de la Cueva $\left(22^{\circ} 50^{\prime} \mathrm{S}, 65^{\circ} 22^{\prime} \mathrm{W}\right)$, Quebrada de Humahuaca, Jujuy Prov. Coll and subm Jan 1984 by S Basilico de Valter and R Brito, Secy Cult Educ, Jujuy Prov.

Comments (MT): assoc with abundant domestic ware and La Isla ceramic style together with faunal remains corresponding to Middle and Late Formative period of Quebrada de Humahuaca region.

\section{LP-144. Cueva Traful III}

$4120 \pm 80$

Charcoal from hearth at 3.65-3.87m depth, Layer 17, Traful III (also known as Los Maitenes Cave) $\left(40^{\circ} 42^{\prime} 15^{\prime \prime} \mathrm{S}, 71^{\circ} 09^{\prime} \mathrm{W}\right)$, Valle Encantado, Los Lagos, Neuquén Prov. Coll and subm April 1985 by D Curzio, Prog Estudios Prehist, CONICET-UBA.

Comment (DC): sample corresponds to first preceramic occupation of cave assoc with some flakes.

\section{Alero Los Cipreses series}

Samples from archaeologic site Alero Los Cipreses $\left(40^{\circ} 38^{\prime} 45^{\prime \prime} \mathrm{S}, 71^{\circ} 19^{\prime} \mathrm{W}\right)$, Traful Lake, Neuquén Prov. Coll and subm March 1985 by M Silveira, Inst Antropol, UBA.

LP-145. PTA-6 no. 9

$1510 \pm 90$

Charcoal from hearth at $0.45-0.5 \mathrm{~m}$ depth, Quad 3. 
LP-159. PTA-6 no. 12

$3490 \pm 80$

Charcoal from hearth at $0.70-0.75 \mathrm{~m}$ depth, Layer 4, Quad 6.

General Comment (MS): date should determine chronologic framework for ceramic and nonceramic components of site.

\section{Casa Piedra de Ortega series}

Charcoal from Casa Piedra de Ortega, Paraje Corralito ( $\left.40^{\circ} 44^{\prime} \mathrm{S}, 70^{\circ} 42^{\prime} \mathrm{W}\right)$, Pilcaniyeu, Río Negro Prov. Coll and subm March 1985 by E Crivelli, Fac Filosofía y Letras, UBA.

\section{LP-146. CPO 10/85}

$2840 \pm 80$

Charcoal from hearth at $1.43-1.48 \mathrm{~m}$ below datum, Layer i, Quad G3.

Comment (EC): dates first occupation of cave and gives terminus ante quem for engravings in bedrock.

\section{LP-168. CPO 5/86}

Charcoal at 1.25-1.29m below datum, Layer e2, Quads G1 and H1.

Comment (EC): dates aceramic phase of northern Patagoniense lithic industry.

General Comment (EC): both dates agree with cave's stratigraphy as well as with other dates from same site (all unpub): AC-951: $2710 \pm 100$ from Layer H; AC-936: $1440 \pm 80$ from Layer 3; LP191: $280 \pm 50$ from Layer e2.

\section{LP-156. Talampaya}

$1830 \pm 60$

Wooden artifact (Larrea $\mathrm{sp}$ ) identified by L Berridi and R Mamblona, Esc Sup Bosques UNLP, from Talampaya site $\left(29^{\circ} 46^{\prime} 05^{\prime \prime} \mathrm{S}, 67^{\circ} 46^{\prime} 07^{\prime \prime} \mathrm{W}\right)$ Independencia, La Rioja Prov. Coll and subm Sept 1985 by M Gonaldi, Inst Antrop, Univ Prov La Rioja.

Comment (MT): from man-made lookout dug into rocky scarp assoc with other wooden objects, basketry, leather, wool, feathered sticks, maize and a domestic-ware sherd, which were lying on a bed of straw and branches, covered by a thick layer of pebbles. Date is related to Early Formative period of Valliserrana region of northwestern Argentina.

\section{LP-157. Playa Grande no. 9}

$1800 \pm 80$

Charcoal from shell midden at $0.10 \mathrm{~m}$ depth, Playa Grande $\left(48^{\circ} 58^{\prime} \mathrm{S}, 67^{\circ} 27^{\prime} \mathrm{W}\right)$ Santa Cruz Prov. Coll and subm March 1986 by A Cardich, FCNyM, UNLP.

Comment (MT): should date Santa Cruz's coastal occupation.

LP-160. Punta Bustamante

$3200 \pm 80$

Charcoal at $0.35 \mathrm{~m}$ depth, $70-80 \mathrm{~m}$ amsl at $1500 \mathrm{~m}$ off shoreline, from Rudd I site $\left(51^{\circ} 33^{\prime} 30^{\prime \prime}\right.$ S, 68 $58^{\prime} 40^{\prime \prime}$ W), Punta Bustamante, Guer Aike, Santa Cruz Prov. Coll and subm Feb 1985 by E Mansur, Centro Austral Investigaciones Científicas, CADIC. 
LP-165. La Huerta

Charcoal from refuse area at $1.45-1.78 \mathrm{~m}$ depth, Quad C1, Layer XV-XVI, La Huerta $\left(23^{\circ} 30^{\prime}\right.$ S, $65^{\circ} 20^{\prime}$ W), Quebrada de Humahuaca, Jujuy Prov. Coll and subm May 1986 by R Raffino, FCNyM, UNLP.

Comments (RR): this date shows Inka-Humahuaca cultural contact in NW Argentina. (MT): date corresponds to refuse area in center of La Huerta town; related to pre-Inka phase of site. Upper layers show cultural contact between Humahuaca and Inka cultures and European objects.

\section{LP-166. Los Flamencos I}

$3100 \pm 110$

Bone collagen (Lama sp) from Los Flamencos I ( $37^{\circ} 40^{\prime} \mathrm{S}, 62^{\circ} 25^{\prime} \mathrm{W}$ ), Campo Fernandez, Saavedra, Buenos Aires Prov. Coll and subm May 1986 by A Austral, FCNyM, UNLP.

Comment (MT): sample from upper layers of archaeologic stratigraphy of non-ceramic component. Date should provide chronologic framework for pampean pottery, resulting in date somewhat later than expected (4000 BP).

\section{LP-167. Lago San Roque}

$3500 \pm 110$

Human bone collagen at $0.70 \mathrm{~m}$ depth, Lago San Roque Beach $\left(31^{\circ} 22^{\prime} \mathrm{S}, 64^{\circ} 33^{\prime} \mathrm{W}\right)$, Carlos Paz city, Cordoba Prov. Coll and subm Jan 1987 by Poder Judicial de Cordoba (Cordoba Dept Justice).

Comment: data requested for judicial investigation.

\section{LP-169. Susques}

$400 \pm 100$

Wood (Trochocereus sp) from roof of house, Susques ( $\left.23^{\circ} 16^{\prime} \mathrm{S}, 66^{\circ} 16^{\prime} \mathrm{W}\right)$, Jujuy Prov. Coll, identified and subm May 1986 by A Fernandez Distel.

Comment (AFD): date should provide chronologic framework for architectural structures related to Late Regional Developments period of Puna de Atacama region.

\section{REFERENCES}

Aschero, C 1980 Comentarios acerca de un fechado radiocarbónico del sitio Inca Cueva 4, Dept de Humahuaca, Jujuy, Argentina. Rev Relaciones Soc Argentina Antropol, ns XIV(1): 165-167.

Ceballos, R and Peronja, A 1983 Informe preliminar sobre el arte rupestre de la Cueva Visconti, Provincia de Río Negro. Rev Relaciones Soc Argentina Antropol, ns XV: 109-119.

Crivelli Montero, E, Eugenio, E and Silveira, M 1987-1988 El sitio Fortin Necochea (Provincia de Buenos Aires). El material de superficie. Paleoetnologica IV: 7-37.

Fidalgo, F, de Francesco, F and Colado, U 1973 Geología superficial en las hojas Castelli, J M Cobo y Monasterio (Pcia de Buenos Aires). In Geol Argentina Cong, 5th, Actas IV: 27-39.

Fidalgo, F and Tonni, E 1983 Geología y paleontología de los sedimentos encauzados del Pleistoceno tardio y Holoceno en Punta Hermengo y Arroyo Las Brusquitas (Partidos de General Alvarado y General Pueyrredon, Provincia de Buenos Aires). Ameghiniana XX(3-4): 281-296.

Figini, A, Gomez, G, Carbonari, J, Huarte R and Zubiaga, A 1984 Museo de La Plata radiocarbon measurements I: Radiocarbon 26(1): 127-134.

Hernandez Llosas, M, Renard, S and Podesta, M 1983-1985 Antumpa. Cuadernos Inst Nac Antropol noticias 10: 525-531.

Huarte, R and Figini, A 1988 La Plata Radiocarbon Laboratory-Liquid scintillation counting and inter-laboratory check samples. Radiocarbon 30(3): 347-350.

Longin, R, $1971 \mathrm{New}$ method of collagen extraction for radiocarbon dating. Nature 230: 241-242. 